\title{
Morphological and Physicochemical Parameters of Three Mango (Mangifera Indica L) Varieties Exported In North of Ivory Coast
}

Toure Abdoulaye $^{1 *}$, Soumahoro Souleymane ${ }^{2}$, Kouame Maïmouna Liliane ${ }^{2}$, Tuo Chigata Drissa ${ }^{2}$, Zoro Armel Fabrice ${ }^{1}$, Soro Yadé Réné 2,3

${ }^{1}$ Biotechnology and Valorization of Agroresources and Natural Substances Laboratory, Faculty of Biological Sciences, Peleforo Gon Coulibaly University, Ivory Coast

${ }^{2}$ Biochemistry, Microbiology and Valorisation of Agricutural Resources Laboratory, Agropastoral Management Institute, Peleforo Gon Coulibaly University, Ivory Coast

${ }^{3}$ Biotechnology Laboratory, Faculty of Biosciences, Félix Houphouët-Boigny University, Ivory Coast

\section{Article History}

Received: 30.09 .2020

Accepted: 15.10 .2020

Published: 21.10 .2020

Journal homepage:

https://www.easpublisher.com/easjnfs

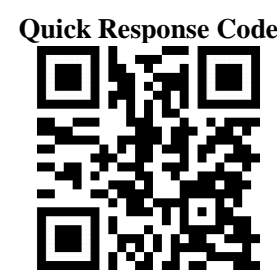

Abstract: The main mango (Mangifera indica L.) production area is located in the North of Ivory Coast. But, the only quality parameters controlled for mangoes exported by packing stations in these localities are morphological and sensory criteria. Therefore, present study which focuses on three mango varieties (Kent, Amelie and Keitt) grown in Northern Ivory Coast, aims to evaluate their morphological characteristics and the physicochemical properties of their pulp. Thirty (30) mango samples constituted of ten (10) fruits of each variety were provided by packing stations of SODIPEX Company (Korhogo, Ivory Coast). Morphological and physicochemical characteristics of the three mango varieties were analyzed at Laboratory of Peleforo Gon Coulibaly University (Korhogo, Ivory Coast). The morphological parameters included caliber index, sphericity index and shape coefficient of each mango sample were evaluated. The proportions of different parts of mangoes (kernel, pulp and peel) were also determined. The physicochemical properties of mango pulps were analyzed for their moisture, $\mathrm{pH}$, and acidity and reducing sugar. For morphological parameters, the results showed the caliber indexes of the three mango varieties varying from $9.01 \pm 0.28$ to $9.89 \pm 0.50$ were in range export criteria of European Union. Their sphericity indexes were ranged from an average of $1.36 \pm 0.03$ to $1.49 \pm 0.06$ and their shape coefficients were between $1.13 \pm 0.06$ and $1.29 \pm 0.20$. Therefore, these morphological parameters were indicated that the three (03) mango varieties have elongated shape. However, according morphological indicators, Kent variety has the best characteristics for export. Study of proportions of mango varieties parts revealed with respectively $80.36 \pm$ $2.06 \%$ and $82.04 \pm 3.27 \%$, Amelie and Keitt varieties have the high pulp contents. Kent variety has the lowest pulp proportion with $72.14 \pm 1.74 \%$. Physicochemical properties analysis showed Keitt and Amelie varieties contain high moisture of $82.80 \pm 3.16 \%$ and $84.80 \pm 2.70 \%$ respectively compared to Kent variety which only contains $77.80 \pm 1.75 \%$. All mango varieties are acidic with $\mathrm{pH}$ values of $3.41 \pm 0.30 \%$ to $3.67 \pm 0.12 \%$ and titratable acidities of $0.19 \pm 0.04 \mathrm{meq} / 100 \mathrm{~g}$ to $2.00 \pm 0.58 \mathrm{meq} / 100 \mathrm{~g}$. Amelie variety have the high titratable acitdity. For reducing sugar content, Kent and Keitt varities have the highest values with $26.10 \pm 0.27 \%$ and $25.10 \pm 0.29 \%$ respectively. The results of this work could constitute a necessary database for marketing, exporting and processing of these three (03) mango varieties studied.

Keywords: Magnifera indica L., mango varieties, Kent, Amelie, Keitt, morphological parameters, physicochemical properties, SODIPEX Company, Korhogo, Ivory Coast.

Copyright (C) 2020 The Author(s): This is an open-access article distributed under the terms of the Creative Commons Attribution 4.0 International License (CC BY-NC 4.0) which permits unrestricted use, distribution, and reproduction in any medium for non-commercial use provided the original author and source are credited.

\section{INTRODUCTION}

Mango is a fruit from tree belonging to species Mangifera indica L. and family of Anacardiaceae growing in tropical and subtropical regions of the world. It is one of the most cultivated fruit species in the world with a production of more than thirty (30) million tonnes. The share of mango on world market has multiplied by five (05) in ten (10) years and exceeds 550,000 tonnes, all markets combined [1]. During 2016, around 336,000 tonnes of mangoes were imported into European countries [2]. Annual production of mangoes in Ivory Coast oscillates between 100,000 and 150,000 with a turnover of around 10 billion FCFA. This performance has raised this country as the leading mango producer in Africa. With more than 30,000 tonnes of mangoes from 2016 to 2017, Ivory Coast is the third exporté of this fruit behind Peru and Brazil [3]. The mango production area in this country is located in 
the North, precisely in localities of Korhogo, Sinematiali, Ferkessedougou and Boundiali. For export of mangoes from these cities to Europe, there are several packing companies. However, export of mangoes to Europe countries requires several quality standards such as morphological, sensory and safety criteria only. Therefore, present study which focuses on three mango varieties (Kent, Amelie and Keitt) grown in Northern Ivory Coast, aims to evaluate their morphological characteristics and the physicochemical properties of their pulp.

\section{Materials ANd Methods}

\section{Selection of mango varieties samples}

This study was conducted in collaboration with the exporting company SODIPEX in Korhogo (Ivory Coast) which provided samples of the three mango varieties studied. Thirty (30) samples of mangoes were chosen in the period from May to June 2019 for this study. These samples consisted of the three (03) mango varieties (Kent, Amelie, Keitt) that SODIPEX company exports. Each variety consisted of ten (10) mangoes samples randomly selected from ten (10) lots of mangoes from different producers. The lots themselves were randomly selected from a set of more than fortyfive (45) lots for each variety. The mangoes were taken in batches (one mango per batch) and followed by marking to identify them (noted from P1 to P10 followed by the initial of the name of the variety). Morphological and physicochemical characteristics of the three mango varieties were analyzed at Laboratory of Peleforo Gon Coulibaly University (Korhogo, Ivory Coast).

\section{Evaluation of morphological parameters of mangoes}

The studied parameters included the length, width, thickness and circumference of the mangoes. These geometrical quantities considered in the appreciation of the morphology of the mangoes, were measured by means of an adhesive tape. The measurements were plotted on a ruler of thirty centimeters $(30 \mathrm{~cm})$. The thickness was measured by considering the major latitudinal side up to the tail of the mangoes. The volume is approximately estimated by considering that the shape of the fruits is parallelepiped [4]. The volume is expressed by formula (1).

Volume $=$ length $\mathrm{x}$ width $\mathrm{x}$ thickness

The shape of the mangoes was assessed by the grade index (Ic) with formula (2) and the sphericity index (Is) with relation (3) according to the formulas used by Silou [5]. The shape coefficient (Cf) expressed with the formula (4) used by Fagbohoun \& Kiki [6], Passannet et al. [7] and Frehaut [4].

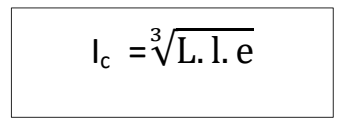



with L: lengh ; 1 : width ; e : thickness.
The grade index indicates the number of fruits (6 to 12 fruits depending on their size) which can contain in a 4 or $5 \mathrm{~kg}$ box. For a mango to be exportable, one of the requirements criteria of the European Union (EU) is that the grade index must be between 6 and 12, inclusive [8]. The sphericity index could show that the shape of the fruit agrees with that of a sphere. So the higher this index, the more the shape of the fruit could tend towards that of a sphere.

The shape coefficient (Cf) allows varieties to be classified into three (03) shape categories which are the mango is flattened $(\mathrm{Cf}<0.8)$, elongated $(\mathrm{Cf}>1)$ and round in sharpe $(0.8<\mathrm{Cf}<1)$.

\section{Determination of proportions of pulp, peel and kernel of mangoes}

The total weight of the fruit was determined using a balance of precision (OHAUS brand, CS200E type, USA). The measures of the mass of the components of the fruit were determined by weighing, according to the methods of Diakabana et al. [9]. However, the mass of the skin was determined by deduction between that of the fruit and the stone. The proportions of the pulp (Pp) and of the kernel (Pn) were calculated respectively by the formulas (5) and (6) used by Passannet et al. [7].

$$
\mathrm{Pp}=(\text { Pulp mass } \times 100) / \text { Mango mass }
$$

$\mathrm{Pk}=($ Kernel mass $\times 100) /$ Mango mass 


\section{Extraction of mangoes pulp}

Each sample of mango was weighed and then peeled before cutting its pulp. The pulp was finely ground using a Blender (NASCO brand, BL1008A-CB type, CHINA). The ground materials (pulp) was put into tubes and frozen until its use for physicochemical analyzes.

\section{Analysis of physicochemical parameters of pulp of mango varieties \\ Moisture of mangoes \\ The moisture content was determined} according to the AOAC [10] method, used by Baudelaire [11] and Belem et al. [12]. The capsules for analysis was cleaned, dried in an oven at $120{ }^{\circ} \mathrm{C}$ and weighed (M0). Then, the capsule containing the sample $(5 \mathrm{~g})$ was weighed (M1) and then placed in the oven at $105{ }^{\circ} \mathrm{C}$ for four (4) hours. After this drying time, the samples were taken out of the oven until a constant mass was obtained. These samples were then cooled in a desiccator for 15 minutes before being weighed (M2) again. The desiccator containing the samples was closed to prevent rehydration of the samples. The moisture content was then calculated according to the formula (7).

$$
\mathrm{TE}(\%)=\left(\mathrm{M}_{1}-\mathrm{M}_{2}\right) /\left(\mathrm{M}_{1}-\mathrm{M}_{0}\right)
$$

With: $\mathrm{M}_{0}$ : mass of capsule,

$\mathrm{M}_{1}$ : mass of capsule with wet sample,

$\mathrm{M}_{2}$ : mass of capsule with dry sample.

\section{pH determination}

For the determination of $\mathrm{pH}$, the potentiometric method of AOAC [10] was used. Ten (10) g of mango pulp were homogenized into (10) $\mathrm{ml}$ of distilled water. After homogenization, the $\mathrm{pH}$ of the mixture was determined using a pHmeter (HANNA brand, HI 8010 type, USA).

\section{Titratable acidity}

Titratable acidity was performed by using AOAC [10]. Titratable acidity was determined by titrated $20 \mathrm{ml}$ of pulp by sodium hydroxide solution $(\mathrm{NaOH}, 0.1 \mathrm{~N})$. The titratable acidity (TA) is obtained according to the formula 8 [4]:

$$
\mathrm{TA}(\mathrm{meq}-\mathrm{g} / 100 \mathrm{~g})=\frac{100 \cdot \mathrm{V}(\mathrm{NaOH}) \cdot \mathrm{N}(\mathrm{NaOH})}{\mathrm{M}}
$$

with: $\mathrm{V}(\mathrm{NaOH})$ : volume of sodium hydroxide $(\mathrm{ml})$

$\mathrm{N}(\mathrm{NaOH})$ : normality of sodium hydroxide (eq-g/l or $\mathrm{N}=0.1 \mathrm{~N})$

$\mathrm{M}(\mathrm{NaOH})$ : mass of sample $(\mathrm{g})$.

\section{Concentration of reducing sugars}

Reducing sugar contents of mango pulp was determined according to Bernfeld D. [13]. To $1 \mathrm{ml}$ of mango pulp were added successively $0.5 \mathrm{ml}$ of distilled water and $0.5 \mathrm{ml}$ of 3.5 dinitrosalicylic acid (DNS). The mixture was heated in a water bath at $100{ }^{\circ} \mathrm{C}$ for $5 \mathrm{~min}$. After cooling, $2 \mathrm{ml}$ of distilled water were added to the mixture. The absorbance was measured at $540 \mathrm{~nm}$ using a spectrophotometer (PG Instruments, England). The value of reducing sugar of pulp was determined using a calibration curve of glucose $(0.1 \mathrm{mg} / \mathrm{ml})$ as standard.

\section{Statistical Analysis}

All the analyses were performed in triplicate and data were analyzed using EXCEL and STATISTICA 7.1 (Stat Soft). Some difference between means is evaluated by Duncan's test. Statistical significant difference was stated at $\mathrm{p}<0.05$.

\section{RESUlTS AND DiscusSiON \\ Results}

Morphological parameters of mango varieties

Table 1 presented morphological

characteristics of the mango varieties studied. Statistical analysis showed length and width of the three mango varieties were not significantly different $(p>0.05)$ with mean values of $12.24 \mathrm{~cm}$ and $10.33 \mathrm{~cm}$ respectively. For the other morphological parameters there is a significant difference $(\mathrm{p}<0.05)$ between mango varieties. Thus, the LSD test was used to identify means that were statistically similar. This test showed that circumference of Kent variety was not significantly different form the two other varieties (Amelie and Keitt). For volume there is any significant difference between Amelie and Keitt varieties with mean values of $790.60 \mathrm{~cm}^{3}$. The results showed the caliber index of the three mango varieties varying from $9.01 \pm 0.28$ to 9.89 \pm 0.50 were in range export criteria of European Union. Their sphericity index were ranged from an average of $1.36 \pm 0.03$ to $1.49 \pm 0.06$ and their shape coefficients were between $1.13 \pm 0.06$ and $1.29 \pm 0.20$. According morphological parameters, Kent variety has the highest values. 
Table-1: Morphological parameters of mango varieties studied

\begin{tabular}{|c|c|c|c|c|c|}
\hline & \multicolumn{3}{|c|}{ Mango varieties } & \multicolumn{2}{|c|}{ Statistics } \\
\hline & Kent & Amelie & Keitt & $F$ & $\boldsymbol{P}$ \\
\hline \multicolumn{6}{|c|}{ Morphological characteristics } \\
\hline Thickness (cm) & $7.30 \pm 0.34^{\mathrm{a}}$ & $6.58 \pm 0.56^{b}$ & $6.05 \pm 0.38^{\mathrm{c}}$ & 19.26 & $<0.001$ \\
\hline Circomference $(\mathrm{cm})$ & $33.34 \pm 1.11^{\mathrm{ab}}$ & $34.00 \pm 1.38^{\mathrm{a}}$ & $32.44 \pm 0.91^{\mathrm{b}}$ & 4.69 & 0.018 \\
\hline Length (cm) & $12.15 \pm 0.61^{\mathrm{a}}$ & $12.35 \pm 0.86^{\mathrm{a}}$ & $12.22 \pm 0.58^{\mathrm{a}}$ & 0.21 & 0.115 \\
\hline Width (cm) & $10.72 \pm 0.86^{\mathrm{a}}$ & $10.33 \pm 0.81^{\mathrm{a}}$ & $9.94 \pm 0.53^{\mathrm{a}}$ & 2.74 & 0.082 \\
\hline Volume $\left(\mathrm{cm}^{3)}\right.$ & $975.33 \pm 148.49^{\mathrm{a}}$ & $846.91 \pm 153.14^{b}$ & $734.29 \pm 70.00^{b}$ & 8.29 & $\approx 0.002$ \\
\hline \multicolumn{6}{|c|}{ Morphological indicators } \\
\hline Caliber index & $9.89 \pm 0.50^{\mathrm{a}}$ & $9.43 \pm 0.61^{b}$ & $9.01 \pm 0.28^{b}$ & 7.84 & 0.002 \\
\hline Sphericity index & $1.36 \pm 0.03^{\mathrm{c}}$ & $1.44 \pm 0.07^{b}$ & $1.49 \pm 0.06^{\mathrm{a}}$ & 13.37 & $<0.001$ \\
\hline Shape coefficient & $1.13 \pm 0.06^{b}$ & $1.29 \pm 0.20^{\mathrm{a}}$ & $1.25 \pm 0.20^{\mathrm{ab}}$ & 3.91 & 0.032 \\
\hline
\end{tabular}

When for the same line, the superscript letters $(a, b, c)$ are identical, the averages are identical at the $5 \%$ threshold.

Otherwise, the means are significantly different at the 5\% threshold according to Fisher's LSD test. Mean $(M) \pm$ standard deviation $(\delta)$.

\section{Proportions of pulp, peel and kernel of mango varieties}

Proportions of different parts of the mango varieties studied were indicated into Table 2. Statistical analysis revealed no significantly difference $(p>0.05)$ between the pulp of the three mango varieties with mean values of $78.18 \pm 2.36 \%$. Peel and kernel were significantly different $(\mathrm{p}<0.05)$ between mango varieties. Kent variety possessed the highest proportions of peel and kernel with $17.07 \pm 0.19 \%$ and $10.79 \pm 1.15$ $\%$ respectively. Amelie has a smaller kernel (4.75 \pm $0.93 \%$ ) while the Keitt possessed the lowest proportion of peel $(10.18 \pm 0.34 \%)$.

Table-2: Proportions of pulp, peel and kernel of mango varieties

\begin{tabular}{|l|l|l|l|l|l|}
\hline \multirow{2}{*}{ Parts of mango } & \multicolumn{3}{|c|}{ Mango varieties } & \multicolumn{2}{c|}{ Statistics } \\
\cline { 2 - 6 } & Kent & Amelie & Keitt & $\boldsymbol{F}$ & $\boldsymbol{P}$ \\
\hline Pulp (\%) & $72.14 \pm 1.74^{\mathrm{b}}$ & $80.36 \pm 2.06^{\mathrm{a}}$ & $82.04 \pm 3.27^{\mathrm{a}}$ & 47.03 & $<0.001$ \\
\hline Kernel (\%) & $10.79 \pm 1.15^{\mathrm{a}}$ & $4.75 \pm 0.93^{\mathrm{c}}$ & $7.78 \pm 1.53^{\mathrm{b}}$ & 60.52 & $<0.001$ \\
\hline Peel (\%) & $17.07 \pm 0.19^{\mathrm{a}}$ & $14.89 \pm 0.18^{\mathrm{b}}$ & $10.18 \pm 0.34^{\mathrm{c}}$ & & \\
\hline
\end{tabular}

When for the same line, the superscript letters $(a, b, c)$ are identical, the averages are identical at the $5 \%$ threshold.

Otherwise, the means are significantly different at the 5\% threshold according to Fisher's LSD test. Mean $(M) \pm$ standard deviation $(\delta)$

\section{Physicochemical parameters of pulp of mango varieties}

Physicochemical parameters of pulp of different mango varieties were summured in table 3. Statistical analysis showed that there is a significant difference $(\mathrm{p}<0.05)$ due to at least one variety of mango studied. The moisture contents of the Amelie and Keitt were the highest with $84.80 \pm 2.70 \%$ and
$82.80 \pm 3.16 \%$ respectively. The Amelie and Keitt varieties have the lowest $\mathrm{pH}$ at $3.58 \pm 0.21$ and $3.41 \pm$ 0.30 respectively. However, the pulp of Amelie variety is more acidic according to its titratable acidity value $(2.00 \pm 0.58$ méq-g/100g). Kent and Keitt have the sweetest pulps with respective levels of reducing sugars of $2.61 \pm 0.27$ and $2.51 \pm 0.29 \mathrm{~g} / \mathrm{l}$.

Table-3: Physicochemical parameters of pulp of mango varieties

\begin{tabular}{|l|l|l|l|l|l|}
\hline \multirow{2}{*}{ Physicochemical parameters } & \multicolumn{3}{|c|}{ Mango varieties } & \multicolumn{1}{c|}{ Statistics } \\
\cline { 2 - 6 } & \multicolumn{1}{|c|}{ Kent } & Amelie & \multicolumn{1}{c|}{ Keitt } & $\boldsymbol{F}$ & \multicolumn{1}{|c|}{} \\
\hline Moisture (\%) & $77.80 \pm 1.75^{\mathrm{b}}$ & $84.80 \pm 2.70^{\mathrm{a}}$ & $82.80 \pm 3.16^{\mathrm{a}}$ & 19.20 & $<0.001$ \\
\hline pH & $3.67 \pm 0.12^{\mathrm{a}}$ & $3.58 \pm 0.21^{\mathrm{ab}}$ & $3.41 \pm 0.30^{\mathrm{b}}$ & 3.55 & 0.043 \\
\hline Titratable acidity (meq-g/100g) & $0.19 \pm 0.04^{\mathrm{c}}$ & $2.00 \pm 0.58^{\mathrm{a}}$ & $1.03 \pm 0.35^{\mathrm{b}}$ & 53.37 & $<0.001$ \\
\hline Reducing sugar (g/l) & $2.61 \pm 0.27^{\mathrm{a}}$ & $1.80 \pm 0.53^{\mathrm{b}}$ & $2.51 \pm 0.29^{\mathrm{a}}$ & 13.44 & $<0.001$ \\
& & & & & \\
\hline
\end{tabular}

When for the same line, the superscript letters $(a, b, c)$ are identical, the averages are identical at the 5\% threshold.

Otherwise, the means are significantly different at the 5\% threshold according to Fisher's LSD test. Mean (M) \pm standard deviation $(\delta)$ 


\section{DISCUSSION}

The morphological properties of mangoes studied showed that these varieties exported in North of Ivory Coast were in range export criteria of international market. Kent and Amelie varieties have significantly higher values of these parameters compared to the Keitt variety. These results could be explained by the capacity of absorption of mineral elements by the roots, by the capacity of carrying out photosynthesis and the composition of the fruit. According Passannet et al. [7] study in Chad the speed production of assimilates of an organ resulting from both its photosynthetic activity and of its size. As for the volume, it could be a visual trait of appreciation of the amount of pulp (flesh) or mass of a mango. The values of volumes and masses would evolve together. This that observed by Frehaut [4] who showed that the volume and mass of fruits increase with the available amount of assimilates (higher number of leaves per fruit). In addition, Triboi \& Triboi-Blondel [14] revealed that final mass and composition of the fruit depend on the availability of carbon (C) and nitrogen (N) assimilates and the functioning of the photosynthetic organs, number and size of cells, number of storage wells, fruit load and number of leaves per fruit. Finally, according to Lechaudel \& Joas [15], the nucleus is the compartment with the highest tissue building costs, followed by the skin and then the pulp. This implies that the fruits with large pits, pulp and skins (Kent and Amelie) would require a substantial force.

The grade index, in business, would be used to classify mangoes according to their shapes for packaging in cardboards. It is positively correlated with the volume, the dimensions of the fruit and varies according to the different varieties. The results showed that its values for the three studied mango varieties were within the range of acceptable values by the European Union (EU) for this indicator. These values were substantially similar to the results of Passannet et al. [7] which were $9.72 \pm 0.50$ for Kent and $9.52 \pm 0.60$ for Keitt. Moreover our values were appreciably close to those of Diakabana et al. [9] who in their studies on the Boko mango in Cameroon, found a size of $8.62 \pm 1$ (when the values of lengths (L); width (1) and thickness (e) were expressed in centimeter $(\mathrm{cm})$ ). In addition, Lechaudel \& Joas [15] showed that the size of the fruit is a quality criterion that strongly depends on the accumulation of water and dry matter in the three (03) compartments of the fruit: the stone, the pulp and the skin.

The sphericity index (Is) and the shape coefficient (Cf) of the studied mango varieties were greater than those of Passannet et al. [7] which were respectively between $0.64 \pm 0.05$ and $0.88 \pm 0.07$ and between $1.12 \pm 0.07$ and $1.78 \pm 0,09$. This would mean that the mango varieties exported by SODIPEX company were all elongated because their coefficient form is greater than $1(\mathrm{Cf}>1)$. The elongated shape of the mangoes of all these varieties could mean that the coefficient form did not depend on the variety of the mango and this characteristic could be determined genetically. The proportion of pulp and stone of these varieties vary respectively between $72.14 \pm 1.74 \%$ and $82.04 \pm 3.27 \%$ and between $4.75 \pm 0.93 \%$ and $7.77 \pm$ $1.53 \%$. These results showed a higher pulp content of the Keitt variety compared to Kent and Amelie. These results were corroborated by those of Laroussilhe [16] who classifies Kent and Keitt among the pulpy varieties.

The study of the physicochemical parameters of mangoes could be necessary and important in the context of a transformation of the mango for export. Indeed after harvest, a ripening process followed by senescence would be triggered into the mango. This could be noticed by an increase in $\mathrm{pH}$ and sugar level, a decrease in acidity, water content and also a loss of firmness. However, the studied characteristics (water and dry matter content, $\mathrm{pH}$, titratable acidity and reducing sugar concentration) depend on the variety of mango. According to Kameni et al. [17], the chemical characteristics of mango vary according to the variety and the level of maturity. The moisture contents of the studied varieties showed the richness of the Amelie variety in water. About moisture, Chacko [18] showed that the water content of fresh fruits varied from $65 \%$ to $95 \%$. For titratable acidity, all the studied varieties were acidic. Amelie variety possessed the high titratable acidity. Belem et al. [12] were observed the same results in Burkina Faso who, in their analysis on three varieties of dried mangoes. These authors were obtained an acidity of $1.56 \pm 0.6 \mathrm{meq} / 100 \mathrm{~g}$ for Amelie against $1.03 \pm 0.98 \mathrm{meq} / 100 \mathrm{~g}$ and $0.71 \pm 0.33 \mathrm{meq} / 100 \mathrm{~g}$ for the Brooks and Lippens varieties respectively. This acidity could be advantageous for Amelie against its deterioration and the development of many microorganisms. Nevertheless, the environment would be favorable to acidophiles [19]. Finally, analysis of reducing sugar gave a higher sugar concentration for Kent, against Keitt and a lower concentration for Amelie. Variability in these concentrations from one variety to another was noted. The difference observed in this analysis could be due to the varietal composition and the stage of maturity of the mangoes according to Belem et al. [12].

\section{CONCLUSION}

The morphological and physicochemical parameters of three (03) varieties of mangoes (Kent, Amelie and Keitt) exported by SODIPEX company (Korhogo, Ivory Coast) were carried out in this research work. For morphological parameters, the results showed the caliber indexes of the three mango varieties were in range export criteria of European Union. Also, their sphericity and their shape coefficients were indicated that the three (03) mango varieties have elongated shape. However, according morphological indicators, 
Kent variety has the best characteristics for export. The study of proportions of mango varieties parts revealed that Amelie and Keitt varieties have the high pulp contents. In addition, physicochemical properties analysis showed Keitt and Amelie varieties contain high moisture compared to Kent variety. All mango varieties are acidic, but Amelie variety have the high titratable acitdity which could it against microorganisms deteriorations. For reducing sugar content, Kent and Keitt varities have the highest values. The results of this work could constitute a necessary database for marketing, exporting and processing of the three (03) mango varieties exported by SODIPEX company.

\section{ACKNOWLEDGEMENT}

The authors would like to express their gratitude to the SODIPEX Company (Korhogo, Ivory Coast) for its collaboration in the collection of samples of mango varieties used in this research work.

\section{REFERENCES}

1. Delroise, A. (2003). Caractérisation de la qualité et études du potentiel de maturation de la mangue (Mangifera indica L.) en fonction de son stade de récolte. CIRAD-FLHOR, La Réunion pôle agroalimentaire, 76.

2. Gerbaud, P. (2017). Marché européen de la mangue. FruiTrop, 247 : 36-36.

3. Seydou, T. (2012). Etude nationale de la mangue, 27

4. Frehaut, G. (2001). Etude de la composition biochimique de la mangue (Mangifera indica L.) en fonction de son stade de maturité. CIRAD FHLOR - Pôle Agroalimentaire, 65.

5. Silou, T. (1996). Le safoutier (Dacryodes edulis), un arbre mal connu. Fruits, 51: 47-60.

6. Fagbohoun, O., \& Kiki, D. (1999). Aperçu sur les principales variétés de tomate locales cultivées dans le sud du Bénin. Bulletin de la recherche agronomique du Bénin, 24: 10-21.

7. Passannet, A.S., Aghofack-Nguemezi, J., et Gatsing, D. (2018). Variabilité des caractéristiques physiques des mangues cultivées au Tchad : caractérisation de la diversité fonctionnelle. Journal of Applied Biosciences, 128: 12932 12942.

8. PIP. (2013). Itinéraire technique mangue (Mangifera indica), CIRAD/UR Hort Sys, 9-15.
9. Diakana, P., Kobawila, S., Massengo, V., Louembe. (2013). Effet du degré de maturation sur la cinétique de fermentation éthylique de la pulpe de mangue cultivar Boko. Cameroun Journal of Experimental Biology, 9(1): 1-8.

10. AOAC. (1990). Official methods of analysis. Association of Official Analytical Chemists Ed., Washington DC, 68.

11. Baudelaire, E.D.N. (2006). Optimisation du broyage des mangues séchées (Mangifera indica variété Kent) : Influence sur les propriétés physicochimiques et fonctionnelles des poudres obtenues. Thèse de Doctorat, Université de Ngaoundéré, 150.

12. Belem, A., Tapsoba, F., Ouattara, L. T. S., Zongo, C., Savadogo, A. (2017). Etude de la qualité organoleptique de trois variétés de mangues Amélie, Lippens, Brooks séchées au cours du stockage par technique de brunissement enzymatique des peroxydases (POD) et des polyphénoloxydases (PPO). Rev. Sci. Technol., Synthèse 34: 38-47.

13. Bernfeld, D. (1955). Amylase B and a. In: Method in enzymology (Colowick S.P. and Kaplan N.O., Eds.), Academic Press, New York, 149-154.

14. Triboi, E., \& Triboi-Blondel, A.M. (2008). Qualité des récoltes et sècheresse. Innovations Agronomiques, 2 :131-158.

15. Lechaudel, M., \& Joas J. (2007). An overview of preharvest factors influencing mango fruit growth, quality and postharvest behaviour. Brazilian journal of plan physiology, 19: 287-298.

16. Laroussilhe, F. (1980). Le manguier, techniques agricoles et productions tropicales, Ed. Maisonneuve et Larose, Paris, 312.

17. Kameni, A., Carll, M., Ngnamtam, Z., Doassem., Lyala, H. (2007). Aptitude au séchage de quelques variétés de mangue cultivées au cameroun : Amélie, Zill, Irwin et Horé Wandou, Fruits, 58 : 89-98.

18. Chacko, E.K. (1986). Physiology of vegetative and reproductive growth in mango (Mangifera indica L.) trees. In: Proceedings of the First Australian Mango Research Workshop. Melbourne: CSIRO, 54-70.

19. Millogo, J. (2012). Caractérisation physicochimique de la mangue sechée biologique (variété Amelie). Mémoire de fin cycle, Université Polytechnique de Bobo Dioulasso (UPB), 54. 